\title{
Doutrina de Precedentes e Organização Judiciária
}

Sidnei Agostinho Beneti'

\section{Do precedente à jurisprudência}

\section{I.I Precedentes e jurisprudência}

O linguajar jurídico nacional vem solapando o conceito de jurisprudência, que é a interpretação consistente dos tribunais a respeito das lides, igualando-a pela de precedente, que é cada julgamento individual. Um julgado não é jurisprudência, mas um precedente, ${ }^{2}$ que interagirá com outros julgados idênticos ou análogos, no sentido da formação, ou não, de jurisprudência.

A lei vive na jurisprudência, de modo que compreensível a afirmaçāo atécnica de que a eficácia da lei controvertida apenas se completa pela afirmação dos tribunais. Daí a importância de uma doutrina de precedentes apta a produzir jurisprudência e da organização judiciária dos tribunais, no sentido de funcionalizar concretamente essa doutrina.

\subsection{Doutrina de precedentes}

Parece contraditório falar em doutrina, termo que implica generalidade, e em precedentes que são essencialmente individuais. A tensão entre legisladores,

\footnotetext{
Ministro do Superior Tribunal de Justiça, ex-Desembargador Presidente da Seção de Direito Público do Tribunal de Justiça de São Paulo, Professor Titular de Direito Processual Civil da Faculdade de Direito de São Bernardo do Campo, Doutor em Direito Processual pela Faculdade de Direico da USP, Presidente Honorário da União Internacional de Magistrados (Roma, <www.iaj-uim >), membro do Instituto Brasileiro de Direito Processual, da Associaçāo Interamericana de Direito Processual e da Associação Internacional de Direito Processual.

2 Muitas vezes se vê em trabalhos judiciais a referência a "jurisprudência", quando da citaçāo de um único precedente, que, evidentemente, não significa interpretação uniforme e consistente da lei pelos tribunais, mormente quando contrastado por outros em sentido diverso.
} 
preocupados em estabelecer normas abstratas, doutrinadores, ciosos da construção científica, e magistrados, trabalhadores do litígio concreto, que têm de encaixar cada caso nas normas e na congruência das categorias científicas, muitas vezes deriva ao verbalismo contundente. Vem de longe a dura crítica aos juízes, que já no longínquo século XIII foram acoimados por BRACTON de "ignorant perverters of the law". ${ }^{3}$

Mas é irrecusável que a individualidade do precedente e a generalidade da norma se completam e não podem prescindir uma da outra, pena de ruir todo o edifício jurídico e de a sociedade enfraquecer-se de sua ausência.

E a contradição é apenas aparente, não real, produto mais da retórica dos diferentes setores da atividade jurídica do que da essência dos conceitos produzidos pelo intelecto humano, que constrói, ao lado do mundo recebido da natureza, esse admirável mundo da cultura, em que se insere o Direito. Dedução e indução, ${ }^{4}$ os dois métodos clássicos do raciocínio se vêem absolutamente congruentes na formação da doutrina direcionadora dos precedentes, assim como destes a formar a doutrina. Por dedução, a norma geral rege o precedente, à custa do silogismo clássico de que todo ser humano é sujeito à norma geral, de modo que este indivíduo, por ser humano, é também a ela subordinado. E por indução, do julgamento de vários casos, digamos, de reconhecimento de culpa, produção de dano e indenização, se extrai a regra de que quem age de maneira idêntica também deverá indenizar.

\subsection{Precedentes em civil law e common law}

Todos os sistemas jurídicos produzem leis e decisões judiciais, isto é, normas e precedentes. Nos sistemas de civil law predomina a metódica elaboração das normas, geralmente organizadas em códigos, ao passo que nos sistemas de common law predomina a força dos precedentes, muitas vezes compondo microssistemas que condicionam até mesmo a admissibilidade da intromissão normativa. ${ }^{5}$

Nos sistemas de common law, os precedentes contêm mais intensa força normogênica. ${ }^{6}$ Nos sistemas de common law os precedentes são efetivamente segui-

BRACTON, Henry de. De Legibus et Consuetuginebus Angliae, 1250-1260, citado na excelente dissertaçāo de AUGUSTO CÉSAR MOREIRA LIMA, para a New York University, Precedentes no Direito, São Paulo, LTR, 2002, p. 20, trabalho de que se extraem várias informaçōes para este escrito.

+ Dedução é o raciocínio que parte da premissa maior e nela encaixa a menor para extrair a conclusāo. Raciocínio principal é o silogismo: todo homem é mortal, Sócrates é homem, logo, Sócrates é mortal. Indução é o raciocínio que parte da observação de qualidades particulares de indivíduos e delas extrai, por abstraçāo da individualidade de cada um deles, a regra geral. O exemplo é clássico: observa-se que o calor dilata o ferro, o ouro, a prata e outros metais e dai se conclui que o calor dilata os metais.

5 Como ocorre no Direito Contratual anglo-americano, em que as cláusulas escritas sāo praticamente inexpugnáveis à alteraçāo pela lei.

- Sobre os sistemas de civil law e common law, entre tantas exposições, destaquem-se JOHN H. MERRIMAN, The civil law tradition, Stanford, Stanford University Press, 1969, e clássica obra de DAVID, René. Os grandes sistemas do direito contemporâneo. Tradução de Hermínio A. Carvalho. $4^{a}$ edição. Martins Fontes, 2002. 
dos, sem que lei nenhuma disponha no sentido de que sejam vinculantes, porque da força deles próprios deriva a vitalidade de cada microssistema em que se inse$\mathrm{rem}^{\dagger}$ em meio ao grande sistema jurídico em que vivem e cujas normas, ao lado da lei, são também produzidas pelos precedentes que mantenham sentido estável, isto é, formem, propriamente, jurisprudência. Nesse sentido, pode-se dizer que os precedentes obrigam a todos, à sociedade e aos aplicadores das leis, conquanto estas não disponham sobre a obrigatoriedade, nem determinem sançōes para o descumprimento. O sistema, ele próprio, vive no precedente estável, que se caracteriza como leading case. Nesse sistema é curiosa a discussão, muitas vezes marcada, aliás, pela soberba - o que é mais retórico do que essencial - a respeito do que é que obriga, se a lei ou se os juízes. ${ }^{8}$ De qualquer forma, prevalece o stare decisis et non quieta movere, ${ }^{9}$ isto é, não se altera o já decidido, sem motivos extremamente relevantes, como a mudança da lei, ou a forte alteração das condições jurídico-sociais subjacentes, que imponha revisão de orientação.

Nos sistemas de civil law os precedentes não contêm potencialidade geradora de norma jurídica, mas apenas interpretam a norma. Não obrigam, porque o que obriga é a norma, de maneira que evidentemente mais tolerada a reabertura de discussão judiciária a respeito da interpretação da lei, embora já realizada pela jurisprudência dos tribunais, ainda que estável - o que não quer dizer que sempre se rediscutam as decisōes judiciais e não se forma jurisprudência nos países de civil law, alguns dos quais, aliás, extremamente resistentes à alteração jurisprudencial sob a mesma lei. ${ }^{10}$

\section{I.4 Observações de Direito Comparado"}

Vale a pena aludir a algumas peculiaridades dos sistemas em que se interligam precedentes, ementas, súmulas e citações.

No common law, precedentes formam verdadeiros postulados, isto é, "verdades fundamentais que condicionam a coerência lógica de um sistema" (MIGUEL REALE).

- ALIOMAR BALEEIRO reproduz a síntese de debate na Suprema Corte dos Estados Unidos, em que o Justice HUGHES realmente disse que "o direito é o que os juizes dizem que é", mas, ulteriormente, o legendário justice FRANKFURTER respondeu, em termos definitivos, que "o direito é aquilo que os juízes dizem que é, mas a lei é que diz a estes o que é o direito" (ALIOMAR BALEEIRO, O Supremo Tribunal Federal, este outro desconhecido, Forense, 1968, p. 45).

- O stare decisis iniciou-se com a publicação dos julgados, desenvolvendo-se ante a invenção da imprensa, não tendo havido discussões ou doutrinas, nem lei a respeito, e parecendo que "sempre existiu", apenas se passando a seguir a regra de treating like cases alike. Prevalece o raciocínio mediante exemplos (EDWARD LEVI, An introduction to legal reasoning, University of Chicago Press, 1949). Sobre a evolução histórica do stare decisis, ver AUGUSTO CÉSAR MOREIRA LIMA, ob. cit., p. 20).

10 O melhor exemplo da persistência jurisprudencial em civil law talvez seja a França, em que o Código Civil de Napoleão, de 1804 (Loi de 30 ventôse, ano XII), rege ainda hoje obrigaçōes e contratos jamais imaginados à época de sua elaboração (registrando-se discussāo, contudo, acerca do Projeto de Alteraçāo do Direito das Obrigaçōes (Projet Catala), elaborado por diversos juristas).

"1 Direito Comparado, sabe-se bem, é expressāo atécnica, porque as fontes normativas sempre sāo nacionais, não havendo uma fonte mundial de "Direito Comparado", mas é elucidativa e consagrada, de maneira que se mantém neste texto. 
a) Reino Unido e Estados Unidos são a terra do comon law, do stare decisis e dos precedentes. ${ }^{12} \mathrm{~A}$ Inglaterra é o berço do common law, que dela se espraiou para os Estados Unidos ${ }^{13}$ e outros países de colonizaçāo britânica. Os precedentes vêm de sua história jurídica, decorrentes do princípio da supremacia do Parlamento, que não somente produz, mas também interpreta a lei, donde a função que seria de Corte Suprema competir à Câmara dos Lordes. As decisões não são ementadas ou sumuladas pelos julgadores, mas são matéria dos editores de jurisprudência, para fins de localização catalográfica. Não são citadas ementas ou súmulas, mas, sim, os julgamentos inteiros, tal como redigidos pelo relator designado pela Corte - após o julgamento, não antes, pois do julgamento participam todos os magistrados, que estudam longamente o caso em conferences, ou seja, reuniōes reservadas dos magistrados, os quais, após verificadas as dissensões e formadas as correntes vencedora e dissidente, designam os relatores de cada um dos blocos para redigir o julgamento (opinion), sendo relator do julgamento, geralmente, o Presidente da Corte, se integrante da maioria, e outro o relator do voto vencido (dissent opinion), lembrando-se que durante os julgamentos ocorre a tentativa insistente de prolação de julgamento unânime. Após tomada a decisão, em conference ${ }^{14}$ sempre secreta, em sala em que não ingressa ninguém, salvo os Juízes, com dever de manter as discussōes em segredo, ocorre a proclamação do julgamento em sessão aberta, presentes todos os Magistrados da Corte para a proclamação, ${ }^{15}$ já redigido o julgamento, cujo texto é assinado por todos. ${ }^{16}$

12 Os precedentes têm muito que ver com a formaçāo filosófica inglesa, ligada ao empirismo de FRANCIS BACON, que remete fortemente ao método indutivo, donde a máxima de que o sistema é de judge made law.

13 O Direito norte-americano acrescentou muito ao common law, como: (a) a existência de uma Constituição escrita nos Estados Unidos; (b) a separaçāo dos Poderes, segundo MADISON, mais acentuada do que em MONTESQUIEU, com a supremacia do Poder Judiciário, nomeado por Executivo e Legislativo ou eleito diretamente pelo povo, mas independente a partir da nomeação; (c) a instituição das Cortes Supremas, compostas por juízes vitalícios, nomeados politicamente mas desvinculados dos organismos políticos (ao contrário da Inglaterra, em que a funçāo de Corte Suprema compete à Câmara dos Lordes - com a grande vantagem institucional, aliás, de o resíduo "legislativo" a ela inerente mitigar a aparência de intromissão do Judiciário no Legislativo, quando a decisāo pudesse ser tida por "contrária" à lei, porque pesa outro dado importante, em sistema de supremacia do Parlamento, que é o de que a lei está sendo interpretada pelo próprio Parlamento, que é apto a modificá-la; (d) o princípio da unidade e da supremacia do Judiciário, que permite o judicial review para controle de atos do Executivo (a partir do leading case "Marbury versus Madison", de 1803, relatado pelo legendário Presidente MARSHALL); (e) a subsistência de duas legislaçôes, a Estadual e a Federal, com a forte reserva legislativa aos Estados, decorrente do federalismo; (f) o presidencialismo norte-americano em contraste com o parlamentarismo inglês.

:t Na Suprema Corte dos Estados Unidos, a conference sempre se realiza às quintas-feiras.

:5 Interessante relato, em caráter jornalístico, do funcionamento do sistema, foi publicado entre nós, em Por detrás da Suprema Corte, de BOB WOODWARD e SCOTT ARMSTRONG, Saraiva, 1985.

16 A assinatura do Acórdāo por todos os integrantes do julgamento é importantíssima. Além de evidentemente fazer melhor a qualidade, ante a correção por todos, não deixa restarem pontos que comprometam julgadores com posiçōes pessoais do redator. Em alguns tribunais, as minutas e os textos dos julgamentos são lançados em folhas de papel com linhas numeradas, de maneira a facilitar a localização de cada linha durante os debates na conference e, posteriormente, a citação em casos futuros. 
Dois pontos são muito importantes para entendimento da consistência na interpretação das normas jurídicas e para a coerência da aplicação aos casos concretos, bem como para a eficiência operacional do sistema: (a) a predominância de reduzido número de magistrados nas cortes superiores; e (b) a obrigatoriedade de descarte de casos repetitivos, sem teses de importância ou irrelevantes do ponto de vista econômico e social. O tratamento desses pontos faz compreender a sobrevivência de sistema, cuja coerência e estabilidade correriam enorme risco de pulverizar-se em uma justiça de ocasião para cada caso, produzindo a aporia no controle social.

Os tribunais superiores são relativamente reduzidos, com poucos magistrados, de maneira que, quando se pronunciam, o julgamento é produto da participação intensa e aprofundada de todos os seus integrantes, de maneira que eliminada qualquer idéia de "loteria" na distribuição do caso, até porque não há o prévio sorteio de relator, surgindo este no decorrer dos trabalhos, pela predominância de opinião ou adequação de sua formação pessoal e de seus argumentos no decorrer dos debates nas reuniões reservadas que se fazem na preparação do julgamento do caso (conference).

De serem pequenos e consistentes os tribunais, decorrem várias conseqüências importantes para a funcionalidade do sistema, p. ex.: (a) a Corte resulta historicamente coerente, pois todos se conhecem e o meio jurídico sabe suas posições, podendo avaliar riscos de ajuizamentos e de resistências; (b) o Presidente da Corte (Chief Judge ou Chief Justice) é realmente o presidente de um todo jurisdicionalmente orgânico, não apenas um administrador, de maneira que cada período da corte é conhecido pelo nome de seu Presidente (fala-se em Corte Warren, Corte Burger, Corte Rehnquist) sem que do fato de a Corte ter um "Chefe" signifique poder de mando jurisdicional sobre os demais magistrados, bem sabido, por exemplo, que durante as Cortes Warren e Burger predominou o posicionamento do Justice Walter Brennan Jr., que nem sempre era o dos presidentes; (c) fica coerente e fácil o descarte, sem nova motivação, de novos casos repetitivos, sem novos argumentos, pois já se sabe de antemão como serão julgados, visto que todos os integrantes da Corte conhecem muito bem as posições de cada um que sejam consistentes e, portanto, imutáveis; (d) nas Cortes intermediárias (p. ex., no Canadá, as provinciais e as cortes federais de apelação nas províncias) é possível o controle prévio da subida dos casos (permission) mediante a decisão de admissibilidade ou recusa - sem recurso - em "rodízio" de integrantes da Corte para audiências de admissibilidade ante a apresentação escrita dos recursos, facultada a ouvida escrita ou oral da parte contrária.

Além disso, a admissibilidade de casos pelos tribunais superiores dá-se por discretionary jurisdiction, "isto é, os recursos são admitidos ou recusados de forma irrecorrível e sem necessidade de motivação, pelos integrantes da Corte, como

O contrário de discretionary jurisdiction é a mandatory jurisdiction, válida para os Juízos de $1^{\natural}$ Grau (Trial Courts) e para casos de apelação, que envolvam fatos. No Brasil, todos os casos são de mandatory jurisdiction, ante a interpretação do art. 5\%, XXXV, da Constituiçāo Federal de 1988, e, ainda, com fundamentação pública e obrigatória, pela interpretação dada ao art. 93, IX, também da Constituição. 
ocorre no melhor exemplo que há sobre a matéria, que é a admissibilidade do Writ of Certiorari ${ }^{18}$ pela Suprema Corte dos Estados Unidos ou pelas Cortes Supremas Estaduais. ${ }^{19}$

Importante dado de introjeção do sentido das decisões no pensamento dos integrantes do meio jurídico e, mesmo, da população, é o fato de os precedentes serem facilmente identificáveis pelo nome das partes, ${ }^{20}$ de modo que a só citação do nome do caso já vale pela exposição do conteúdo, ao contrário do que ocorre entre nós, em que mesmo o mais atento jurista de boa memória dificilmente poderá reconhecer julgamentos simplesmente ao enunciado do número do processo nos tribunais, ou volume e página de repertório de jurisprudência que o tenha publicado. ${ }^{21}$

18 O Writ of Certiorari, na Corte Suprema dos Estados Unidos, não começa pelo ajuizamento de uma petiçāo ou recurso formando um processo, mas pelo envio de nove cópias do caso, uma para cada Justice, cujos Law Clerks, que sāo juristas recém-formados, livremente escolhidos pelos Justices (geralmente mediante indicaçōes ou apenas exame de currículos universitários), por período absolutamente improrrogável de dois anos, preparam memorandos examinando as possibilidades dos casos; os Justices semanalmente selecionam quais os casos aceitariam examinar e os levam, uma ou mais vezes, para a Conference semanal, em que se escolhem, por votação, os casos para serem abertos (se houver quatro votos positivos o caso é aberto, caso contrário é recusado), sem que em nenhum momento haja julgamento escrito motivado, de modo que tanto a admissāo como a rejeiçāo restam irrecorriveis. $O$ Justice Breyer, da US Supreme Court, relatou certa vez em almoço-conferência de que participou o autor deste escrito que cada gabinete de Juiz da Corte Suprema recebe cerca de oitenta pedidos de abertura de casos por semana; seus Law Clerks separam cerca de oito para a Conference semanal e, destes, todos os Justices admitem para julgamento pela Corte dez ou quinze por mês, começando, apenas depois da aceitação, o processo formal - o que explica o número de cerca de cento e cinqüenta processos julgados por ano por toda a Corte, o que é razoável para julgamentos absolutamente seguros, com profundidade e consistência, tornando-se conhecidos e obedecidos em todo o país. Sobre o trabalho de Law Clerks, ver STEVE ALLAN RIESS, Assessores judiciais nos EUA, JUTACRIM, 93/7.

19 As Supremas Cortes Estaduais (State Supreme Courts) corresponderiam no Brasil aos Tribunais de Justiça (mormente antes da extinçāo dos Tribunais de Alçada pela Emenda Constitucional no ${ }^{\circ}$ 45/04), pois nos Estados Unidos, nos Estados de maior volume judiciário, correspondendo aos extintos Tribunais de Alçada, há as Intermediate Courts, as Appellate Courts, que nāo julgam matéria constitucional estadual - sendo de notar que também integradas por poucos Juízes, não ultrapassando, provavelmente, as Supreme Courts e as Appellate Courts, juntas, em nenhum Estado americano, há cinquienta Juízes, nem mesmo nas maiores, que são as dos Estados de New York e Califórnia - donde se vê que não é pelo puro aumento do número de Juízes que se resolve o problema da demanda judiciária.

20 P. ex., "Marbury versus Madison" (poder de revisāo dos atos administrativos pelos tribunais), "Brown versus Board of Education" (não-discriminaçāo nas escolas e transporte escolar), "Roe versus Wade" (regramento constitucional do aborto).

21 A citação de nomes das partes é, entretanto, uma questão séria, sendo proibida, em todos os casos, em alguns países (p. ex., Canadá, em que todos os nomes, até de testemunhas, são eliminados até dos registros), e, entre nós, nos casos de segredo de justiça (CPC, art. 150). Mesmo a citaçāo de nomes de testemunhas e outros figurantes do processo em muitos casos há motivo para ser vedada. Por exemplo, repercussōes trabalhistas de nāo-contrataçāo de empregados que tenham sido reclamantes, ou morais, atinentes à família, ou comerciais e tantas outras. Não se olvide que os casos judiciais, mediante a informação por Internet, são fonte importante de pesquisa para vários interessados, podendo resultar em discriminaçāo. A respeito, veja-se, entre outros, CARLOS GREGORIO, Las reglas de heredia. No Direito norte-americano, contudo, se o caso chegou a Juízo, é público, qualquer que seja, podendo, quem quiser, publicar, desde que respeitadas as regras da liberdade de imprensa (p. ex., não o faça com intuito ofensivo). 
b) A Alemanha é um Estado organizado sob a forma federativa, com sistema inserido no civil law. Não vigora o princípio do stare decisis e os precedentes não obrigam a julgamentos futuros, prevalecendo, sempre, como premissa maior, a lei, no mais puro raciocínio segundo o método dedutivo. ${ }^{22}$ Mas os precedentes possuem enorme força para as decisōes dos tribunais alemães, à força do princípio organizacional típico da sociedade germânica em todos os tempos, geradora de naturais imperativos categóricos ${ }^{23}$ que reforçam a tendência ao cumprimento das normas, quaisquer que sejam.

Precedentes não vinculam, nem obrigam, mas são obedecidos e seguidos. Só existe um caso em que o precedente obriga, ou seja, o da manifestação do Tribunal Constitucional Alemão, situado em Karlsruhe, ${ }^{24}$ quando este anula a lei por inconstitucional..$^{25}$

O sistema respeita naturalmente o precedente. E controla, por outros caminhos que não o stare decisis, a dispersão jurisprudencial. KAUS KINKEL, que foi Presidente da Corte Constitucional Alemã, explicou entre nós, que a divergência entre os Tribunais dos Estados (Länder) ocorre por intermédio da submissão à Câmara Conjunta dos Tribunais Superiores da Federação, ${ }^{26}$ ou seja, o Tribunal Federal de Justiça, ${ }^{27}$ o Tribunal Federal Administrativo, ${ }^{28} \mathrm{o}$ Tribunal Federal do Trabalho ${ }^{29} \mathrm{e}$ o Tribunal Federal Social, ${ }^{30}$ além do próprio Tribunal Federal Constitucional.

Outro importante mecanismo de consistência dos julgamentos resulta da combinação de dois temas de relevo operacional: (a) o princípio da especialização, que evita a repetição de julgamentos, eventualmente em sentidos diversos, por

\footnotetext{
22 O método dedutivo, não se olvide, apresenta o paroxismo no racionalismo tal como exposto principalmente por KANT, ligando-se às fontes principais do racionalismo alemāo, de maneira que nāo surpreende a força com que implantado o civil law na Alemanha, a começar pela ânsia codificadora - de que, aliás, participou, fora da Alemanha, o pensamento francês, também racionalista.

23 O imperativo categórico também se explica, no que aqui importa, em KANT - de maneira que o já decidido é como se fosse um vetor semi-absoluto, nāo escrito, levando à observância em casos idênticos futuros.

24 É curiosa a ubicação dos Tribunais na Alemanha: a cúpula do Poder Judiciário não fica na Capital, mas, sim, em Karlsruhe, como ocorre, aliás, em muitos Estados (Länder), p. ex., Baden Würtenberg, sendo essa ubicação diferenciada das sedes de Executivo e Legislativo (classe política) e Judiciário (magistratura) como que um reforço geográfico à idéia de separação dos Poderes e de diferenciação de formas de raciocínio e decisão.

25. SACHS, Michael. Die Bindung des Bunderverfassungsgericht an seine Entscheidungen, Vahln; 1. Aufl edition, 1977.

25 O Gemeinsamer Senat der oberster Gerichte des Bundes, $\ 100$, s. 2, da Lei Fundamental (Grundgesetz - Lei Fundamental e nāo Constituiçāo, porque outorgada pelas quatro potências de ocupaçāo, após a Segunda Guerra Mundial, e resta assim até hoje!).

2: $\mathrm{BGH}$ - Bundesgerichtshof, equivalente, aproximadamente, ao nosso STJ - Superior Tribunal de Justiça.

28 BVerw $\mathrm{G}$ - Bundesverwaltungsgericht, sem equivalente brasileiro.

29 BAG - Bundesarbeitsgericht, equivalente ao nosso TST - Tribunal Superior do Trabalho.

30 BSG - Bundessozialgericht, sem equivalente brasileiro, competente para questóes previdenciárias e de seguridade pública. Sobre o sistema, ver BEND BARON VON MAYDELL; FRANZ RULAND, Sozialrechtshandbuch, Luchterhand Verlag, 1996.
} 
unidades judiciárias diferentes, princípio que é típico da organizaçāo judiciária alemã, e (b) a utilização da competência funcional para a admissibilidade ou não dos recursos pelos Tribunais.

A especialização domina os Tribunais Superiores alemães, fazendo-se por temas de direito material (p. ex., família, seguros, contratos, insolvência), inclusive pelo próprio direito processual tomado como matéria (p. ex., câmara processual no BGH evita disseminação de divergências em matéria notoriamente geradora delas, como a matéria processual).

A competência funcional descarta previamente matérias já decididas, que se apresentem sem novos argumentos, de maneira que se supõe serão novamente decididas da mesma forma. Nesse sentido, a admissibilidade ou inadmissibilidade de recurso constitucional (Verfassungsklage) realiza-se por câmara (Senat) composta de três juízes da corte, que conhecem, naturalmente, toda a jurisprudência da corte e as posições de seus integrantes, de forma que, se rejeitado o recurso, por esses três juízes, por unanimidade, sem necessidade de motivação escrita e sem cabimento de recurso, o processo não ingressa no Tribunal, tendo-se por recebido, contudo, caso obtenha ao menos um voto em seu favor, porque, nesse caso, ao voto vencido soma-se o prestigiamento do acesso recursal.

O sistema judiciário alemão não contempla o uso de súmulas ou ementas para citações, de modo que, no estudo do precedente, é esquadrinhado o texto integral do julgamento invocado. A exposição histórica, contudo, registra que o Legislativo chegou a criar, por lei, em 1863, a sumulação com vinculação, mas a experiência não vingou.

Os julgados não sāo indicados pelo nome das partes, como no sistema angloamericano, mas muitas vezes assim se conhecem. E, por vezes, se conhecem pelas palavras iniciais do texto ou pelo assunto de que tratam. ${ }^{31}$

$\mathrm{O}$ sistema consegue manter em níveis toleráveis a litigância judicial. $\mathrm{O}$ andamento dos processos é tido por célere, ${ }^{32}$ tendo o país e seus juristas orgulho de registrar reduzida demora no âmbito europeu. ${ }^{33}$

\footnotetext{
31 Um julgado recente muito conhecido pela palavra inicial soeben ("agora mesmo").

32 É célere, mas nāo se imagine um flash: um despejo pode levar três anos e a execuçāo muitas vezes é desesperadora, porque fundada em astreintes econômicas (multas) para desocupação, que evidentemente não são pagas por quem já não paga alugueres; a prisão preventiva decretada em primeiro grau é autorizada por seis meses, mas pode ser prorrogada tantas vezes quantas necessárias, por igual período, só que pelo Tribunal de Justiça (Bundesgerichtshof), e, como já se assinalou, uma causa atinente à Jurisdição Social pode chegar a doze anos, se esgotados todos os recursos!

33 Diante de uma condenação da Alemanha, por demora judicial, pelo Tribunal de Direitos Humanos da Convençāo Européia, em Estrasburgo, a então Presidente da Corte Constitucional Alemã, a grande IUTTA LIMBACH, Professora Titular da Universidade de Berlin, pronunciou-se publicamente apontando a estranheza da condenaçāo no julgamento de difícil questāo, de interesse para todo o país, subindo todos os graus da jurisdiçāo alemã, quando a Corte de Estrasburgo havia demorado anos para a condenação, apesar de pronunciar-se em única instância... Note-se, sobre a matéria, que o Tribunal Europeu de Direitos Humanos, em Estrasburgo, tem demorado em torno de seis anos para julgar cada caso, em instância única, e, muitas vezes, condenando os Estados europeus pela demora no julgamento desses casos... (cf. entrevista ao Deutsche Richterzeitung).
} 
c) A França, também formada em civil law, ${ }^{34}$ é um Estado unitário, com sistema judiciário marcado por muitas singularidades diante dos demais, a começar pela peculiar divisão do poder, de que resulta ao Judiciário a denominaçāo de "atividade judiciária" e não de "poder", ${ }^{55}$ passando pela manutenção do contencioso administrativo para o controle da administração ${ }^{36}$ e pela intensa atividade leiga de profissionais de ofício em tribunais especializados. ${ }^{37}$

O sistema judicial possui três tribunais superiores, com jurisdição final especializada: o Conseil Constitutionnel, a Cour de Cassation e o Conseil d'État.

Os julgamentos raramente citam jurisprudência e é proibido basear julgamentos apenas em prececentes. ${ }^{38}$ Os julgados, contudo, são conhecidos e importantes, especialmente os da Cour de Cassation, podendo, contudo, os tribunais, deixar de segui-los, sem explicar o porquê de não os adotarem. Os julgamentos possuem ementas, mas os julgamentos dos tribunais superiores publicam-se integralmente nas revistas oficiais. Nas publicações especializadas, publicam-se os julgados com anotações doutrinárias, denominadas Notes d'Arrêt, que qualificam, positiva ou negativamente, os precedentes.

De qualquer maneira, pode-se dizer que se forma a jurisprudence constante após seguidos julgamentos, sendo importante lembrar que os julgados são redigidos de maneira muito sólida, e deliberadamente ostentando solidez, tanto que os votos divergentes nunca são publicados, ${ }^{39}$ em que pese, evidentemente, por vezes, a importância de um entendimento divergente fundamentado.

d) A Itália exercita, talvez, o mais acentuado exemplo de civil law. Estado unitário, fundado em Constituição e códigos para cada ramo do Direito, possui organização judiciária piramidal em que grande número de casos pode ascender

34 Não se olvide a influência cartesiana nos fundamentos do pensamento francês, ainda que sob a evoluçāo filosófica ulterior.

35 Essa divisão do Poder é típica do parlamentarismo, menos pronunciada, na formulaçāo de MONTESQUIEU, do que sob o presidencialismo norte-americano, em que a separação dos poderes deu-se com mais vigor na doutrina de MADISON. Mas do fato da denominaçāo "atividade judiciária" não resulta inexistência de independência judicial na França, como alguns observadores apressados em olhar apenas a superfície das instituiçōes algumas vezes concluem.

${ }^{36}$ O contencioso administrativo possui os próprios tribunais, ao lado do Poder Judiciário, até alçar ao Conselho de Estado.

3. Como é o caso das Cortes de Proud'Hommes para as relaçōes do trabalho, as cortes comerciais e as câmaras de insolvência para a recuperação de empresas (em absoluto segredo de atividade, realce-se).

38 Code de Procédure Civile, art. 455.

39 Votos divergentes fornecem ensejo a divagaçōes importantes. Por mais respeitáveis que sejam, e sem dúvida também por isso, acabam enfraquecendo o julgado, pois fornecem ao vencido a impressão de que o julgamento da maioria foi errado. Por outro lado, sistemas totalitários têm impedido a divulgaçāo de votos vencidos, sendo secreta a votaçāo, como ocorria na extinta República Democrática Alemā, em que, após a reunificação alemā, apurou-se que muitos julgamentos criminais, com pesadas condenaçōes, haviam sido tomados por determinaçāo do Partido Comunista no poder, tonnando-se dificil, contudo, responsabilizar os juízes participantes do julgamento, pois entre eles podia estar o prolator de algum voto vencido. 
à última instância judiciária, ${ }^{40}$ a Corte di Cassazione. Com quatrocentos magistrados, julga cerca de 47.000 casos por ano. A matéria administrativa é reservada a sistema próprio (Consiglio di Stato). A Corte Costituzionale, com quinze integrantes, julga aproximadamente 350 casos por ano. A dispersão jurisprudencial é predominante, a ponto de um grande pocessualista, MICHELLE TARUFO, haver escrito que "a jurisprudência formada pelas cortes superiores é uma espécie de loja de departamento, onde cada litigante pode achar qualquer coisa de que precise, se procurar cuidadosamente". ${ }^{41}$

A especialização dá-se apenas nas grandes linhas, a partir da separação da matéria administrativa para o Consiglio di Stato e divisão geral em civil e penal, com poucas especializações, especialmente no âmbito do Ministério Público. ${ }^{42}$ Nos tribunais superiores, votos e decisōes não se tomam sob publicidade obrigatória e não são consignados os votos dissidentes. As decisões são escritas, com profunda fundamentação, assemelhando-se a artigos doutrinários publicados em revistas especializadas. São ineficazes os filtros de relevância, para prévio bloqueio ou descarte de matérias já antes julgadas. Mas existe sistema de prévia unificação da jurisprudência (Sezioni Uniti na Corte di Cassazione e Adunanza Plenaria no Consiglio di Stato).

Precedentes não vinculam, mas, evidentemente, são relevantes. A doutrina de juristas não pode ser citada nos julgamentos (CPCIt., art. 118). ${ }^{43}$

Ementas e súmulas não são matérias das decisões, mas na Corte di Cassazione o Uffizio de Massimario, integrado por magistrados da Corte, elabora extratos (Massime) muito curtos, de poucas linhas, das decisōes. Apenas essas Massime, publicadas em revistas especializadas privadas, são citadas ulteriormente nas decisões.

A dispersão jurisprudencial é de difícil controle, principalmente porque, em sistema que não adota o stare decisis, os tribunais superiores possuem grande número de magistrados, porque as unidades julgadoras concorrem, com a mesma competência, repetindo, muitas vezes contraditoriamente, a decisão do mesmo tema, e porque demorado o sistema de tomada de cada julgamento, o que retarda o pronunciamento final dos tribunais superiores por intermédio de mecanismos processuais como a unificação da jurisprudência pelas Sezioni Uniti e Adunanza Plenaria.

\footnotetext{
40 A Corte Costituzionale, competente apenas para a matéria constitucional, situa-se fora da organizaçāo judiciária e da carreira da magistratura, como tribunal de formaçāo política, cujos integrantes em geral vêm da classe política e acadêmica, com mandado por tempo certo. Da mesma forma o Consiglio della Giustizia, que é órgāo de controle externo do sistema de Justiça, com minoria de Magistrados.

41 TARUFFO, Michele; DA TORRE Massimo. Precedent in Italy. In: MAC CORMICK, N.; SUMMER R. S. (Ed.) Interpreting precedents: a comparative study, Aldershot, 1997. p. 165.

42 Especializadas e muito conhecidas as atuaçōes sobre crime organizado, anti-máfia e mani puliti.

43 Já se ouviu falar que na Inglaterra a citaçāo de escritos doutrinários foi durante muito tempo vedada, passando-se depois a admitir a citação apenas de trabalhos de juristas falecidos, para evitar a elaboração doutrinária de influência no caso.
} 
e) No âmbito Iberoamericano (Espanha, Portugal e países de influência ibérica na América Latina) impera o civil law e os sistemas de processo e organização judiciária se avizinham do sistema italiano, atentando-se, contudo, à enorme confusão sistemática registrada na atualidade, ante as sucessivas tentativas de reforma do sistema judiciário, fundadas em princípios provindos de diferentes origens, muitas vezes contraditórias, ${ }^{44}$ marcados, muitos, por evidente influência política de momento e não raro de profunda nota populista. ${ }^{45}$

Não se formam precedentes estáveis em tempo razoável. Permanece a dissensão jurisprudencial funda durante muito tempo. Surgem os Conselhos da Magistratura, em muitos países, pressionando, claramente, a atuação dos juízes, ainda que sob a afirmação retórica de intangibilidade da liberdade jurisdicional, que, contudo, como nas experiências recentes especialmente de Peru, Venezuela, Equador, Bolívia e Paraguai, ${ }^{46}$ resta fundamente atingida.

44 A contradição sistemática é evidente, por exemplo, no caso brasileiro, em que institutos típicos do julgamento "negociado" do common law, como a plea bargaining (na Lei dos Juizados Especiais e nas reformas do Código de Processo Civil) e a arbitragem (Lei $n^{\circ}$ 9.307, de 23.9.1996) se ajuntam a mecanismos mistos de stare decisis e controle prévio de constitucionalidade, como as súmulas vinculantes (Emenda Constitucional 45/2005), sem introduzir, contudo, os instrumentos processuais que dão praticidade ao sistema processual de common law, como a absoluta oralidade, o nāo-registro e transcrição de atos judiciais intermediários, a inexistência de recursos de decisōes interlocutórias - e, o que é importantíssimo - sem que se altere a estrutura do suporte material do escrito, que entre nós se dá sob o princípio da unicidade dos autos escritos, ao contrário da inexistência de autos ou do registro informatizado (ponto que, entre nós, pōe em risco a viabilidade de eficácia das súmulas vinculantes, pois nos mesmos autos se ajuntam várias teses, as já vinculadamente sumuladas e as por sumular, de maneira que sempre será obrigatória a subida dos autos, nem que seja para separar uma das outras).

4.5 Em grande parte dos países da América Latina, a eleição presidencial acirrada costuma desencadear a tentativa de mudança de integrantes das Cortes Supremas e, onde existentes, de Tribunais Constitucionais, com o conseqüente direcionamento de duras campanhas públicas contra os integrantes dessas cortes. O Brasil, cujos tribunais tem primado por diferenciada independência, tem se situado à margem dessas tentativas. Importante o fato de a renovaçāo do Supremo Tribunal Federal e dos Tribunais Superiores operar-se materialmente devido à compulsoriedade da aposentadoria dos magistrados aos setenta anos. Na Argentina a situaçāo tem sido diversa, ante a vitaliciedade sem limite. Daí a pressão maior, a cada eleiçāo popular acirrada, para o afastamento de magistrados da Corte Suprema, sendo recentes os exemplos de chamados juicios políticos perante o Parlamento, contra todos os Magistrados da Corte Suprema (Presidente Duhalde, sob o argumento de anterior manipulação da Corte Suprema pelo Presidente Menem), e de saídas, a pedido, dos magistrados Nazareno, Presidente da Corte, e Bossert - restando sob juicios políticos outros magistrados, cujo mais significativo exemplo, talvez, seja do Magistrado Fayt. Agravou-se a questão na Argentina ante o reduzido número de Magistrados da Corte Suprema - em número de apenas cinco. Note-se que a essa tentação de interferir não escaparam, felizmente sem sucesso, nem mesmo governantes norte-americanos, como ocorreu após a eleição do Presidente Roosevelt, que, contrariado por decisōes da Suprema Corte contra normas do New Deal, tentou aumentar o número de Juízes da Corte Suprema, projeto, contudo, rechaçado pela classe política, de maneira que o Governo teve de aguardar a evolução normal das vacàncias por aposentadoria voluntária ou óbito.

46. A pressão geralmente se exerce colocando-se os Juizes en comisión, isto é, sob a obrigatoriedade de revisão de nomeações, após processo de recebimento de denúncias, muitas vezes anônimas (Peru e Venezuela), ou de puniçōes com pagamento de multas muitas vezes de valores superiores aos vencimentos, no caso de reforma de decisōes pelo Tribunal Constitucional (Bolívia), ou de pura e simples destituição da Corte, inclusive toda a Corte Suprema, e por duas vezes (Equador). Curioso o processo na Venezuela, em que se adicionaram juizes contratados, nomeados entre Advogados, indicados sem 
Alguns países tentam mecanismos de aceleração da jurisprudência, como, por exemplo, na Argentina, o recurso per saltum, que já permite levar as matérias diretamente às Cortes Superiores. ${ }^{47}$ Portugal inventou eficiente sistema, de dispensar os Juizes dos tribunais de repetir motivação, no caso de manutenção da decisão de $1^{\circ}$ grau pelos seus próprios fundamentos.

\subsection{Destaques sistemáticos}

Observados os sistemas existentes no Direito Comparado, algumas conclusōes parecem claras: (a) a segurança jurídica possui, certo, influência de relevo no desenvolvimento das nações, cotando-se melhor as que mantêm essa segurança; (b) a segurança jurídica pressupōe sistema normativo estável, que produza normas duráveis, para serem trabalhadas, em seguida, pelo Judiciário, sem que se alterem significativamente durante $o$ andamento dos processos até a instância final; (c) não há estabilidade jurídica sem estabilidade normativa, principalmente constitucional; (d) os países de common law chegam com mais rapidez à segurança dos precedentes e os mantêm de maneira mais durável; (e) para produção de precedentes qualificados e duráveis, é necessário tenham sido resultado de exame profundo dos detalhes do caso, inclusive circunstâncias concretas aparentemente individuais, durante o processo de julgamento; ( $f$ ) os sistemas mais estáveis não produzem ementas e súmulas nos próprios atos jurisdicionais, pois o precedente é todo o corpo da decisão e não seu resumo - sobrando súmulas e ementas como questão de dicionários editoriais para a localização de precedentes; (g) não se citam súmulas e ementas na argumentação judicial nos países de jurisprudência mais estável, mas, sim, todo o caso; (h) é importante o nome do precedente para a sua lembrança, geralmente pelo nome das partes envolvidas - embora isso crie realmente problemas de possível discriminação de litigantes; ${ }^{48}$ (i) tribunais reduzi-

concurso, à Corte Suprema, sob o argumento de necessidade de pôr em ordem o serviço, ao mesmo tempo em que os magistrados da Corte Suprema foram sendo compelidos à aposentadoria, até que saiu a Presidente (Cecília Sosa), todos sob a acusação de ligação com governos anteriores, mas passando, alguns juízes novos, certo tempo depois, a também sofrer o mesmo tipo de acusaçāo, quando de decisōes contrárias ao governo - chegando-se, inclusive, à proibiçāo de existência de Associação de Magistrados, tradicional instrumento de defesa dos Juízes, por texto expresso da Constituição Boliviana ora vigente.

47 Algumas vezes com sucesso. Observe-se que a Corte Suprema da Argentina conseguiu julgar com mais rapidez as questões decorrentes da reforma monetária decorrente da desdolarização (corralito) do que o Supremo Tribunal brasileiro (bloqueio de ativos no Plano Collor), mas, como tudo tem conseqüências, da celeridade decorreu choque mais frontal e imediato da Corte Suprema com o Governo, incentivando os Juízos Políticos. No Brasil a acusaçāo aos Tribunais foi de demora; na Argentina, de parcialidade, ante a rápida consolidação de diretriz contrária. Curiosa, nesse ponto, a experiência de Israel, em que as questōes administrativas são julgadas diretamente pela Corte Suprema - com eventual choque direto e imediato, sem arrefecimento pelo tempo, evidentemente, com as políticas de governo, o que pode pôr em risco a Corte ou o Governo.

48 Cf. CARLOS G. GREGÓRIO e SONIA NAVARRO SOLANO, Reglas de heredia, ed. Ad-Hoc, Buenos Aires, 2004. 
dos produzem jurisprudência mais durável, o mesmo ocorrendo com tribunais de grande número de integrantes apenas se neles houver especialização temática de modo que apenas um Órgão (Câmara) seja competente para cada matéria; (j) não há notícia de construção de doutrina efetiva de precedentes em decorrência de lei, resultando ela, sempre, de maturidade político-institucional que leve ao respeito das decisōes judiciais como dado importante para a organização da convivência em sociedade; (l) para viabilização aos tribunais e estabilidade de jurisprudência é necessária a utilização de mecanismo eficaz de prévio descarte de questōes repetitivas ou de reduzida relevância.

\section{Dispersão jurisprudencial no Brasil}

\section{I Os números judiciários nacionais}

Os números judiciários nacionais são imensos. A produção dos juízes nacionais é, de longe, a maior do mundo. ${ }^{49}$ Se se considerar o acesso à Justiça como facilidade de ingressar em juízo ou de subir aos tribunais, inclusive aos tribunais superiores do sistema federativo, o país estará entre os que mais acesso garantem à população.

A Constituição Federal garante o ingresso incondicional em Juízo e limita a criação de filtros de admissibilidade, ${ }^{50}$ como a prévia exigência de decisão administrativa, da jurisdição social alemã, que mantém os casos jurisdicionais relativos à previdência em números razoáveis, impedindo que cada aposentado ou beneficiário se transforme em litigante, ou o princípio da proporcionalidade, implantado na Inglaterra, que obriga o juízo de $1^{\underline{0}}$ grau a rejeitar sumariamente casos cujos custos processuais sejam superiores aos do benefício concreto almejado, ${ }^{51}$ ou, ainda, a seletividade que se implanta nos Estados Unidos, instrumentalizada

49 Os observadores nacionais estão acostumados com esses números, de modo que a demora no julgamento de um caso, para a parte e para o Advogado, é vista como produto da má vontade, preguiça ou tendenciosidade do juiz. Positivamente, o meio jurídico nacional não se impressiona com a quantidade de trabalho de seus juizes e julga que estes trabalham pouco, têm férias demasiadas, nepotismo e "mordomias". Mas comparados aos do foro internacional, os números são inacreditáveis. Bem conhecida a história de que em um congresso internacional, o Min. Sálvio de Figueiredo Teixeira relatava o número de casos por ele relatados durante o ano no STJ e, ao referir-se, em inglês, a one thousand, o presidente da sessão, admirado, pretendeu corrigir o termo para one hundred, já julgando muito! E aí sempre surgem as perguntas do interlocutor estrangeiro: se as decisōes têm de ser escritas, se nāo são fundamentadas, quantas páginas tem um julgado? Mas nāo pára aí o problema: confirmados os números, a obrigatoriedade do escrito, da fundamentação e da publicidade, resta a difícil tarefa de convencer de que os julgamentos têm qualidade, de que os processos foram lidos, que a redação é pessoal, se há assessores, quantos etc! Entre nós, entretanto, vinda de fora do meio jurídico, uma pesquisadora, ao menos, fez justiça em reconhecer que os juizes trabalham, e muito (MARIA TEREZA SADEK).

so $\mathrm{CF}$, art. 5", XXXV.

51 Sobre a modernização geral do Processo Civil Inglès, vide JOSÉ CARLOS BARBOSA MOREIRA, "Uma novidade: o Código de Processo Civil Inglês, Estudos em homenagem ao Min. Adhemar Ferreira Maciel. Saraiva, 2001, p. 451. 
pelo case management, diante do qual uma comissão selecionadora da corte separa os tipos de casos ao início, destinando-os, compulsoriamente, à mediação ou arbitramento, em alguma de suas formas, ${ }^{52}$ à early neutral evaluation ${ }^{53} \mathrm{ou}$, apenas em último caso, à litigation, que é o ajuizamento.

\subsection{A dispersão jurisprudencial}

A dispersão jurisprudencial alimenta os grandes números e estes, por sua vez, acentuam a dispersão.

Os números, evidentemente, embutem o fato de várias vezes decidir-se, em sentidos muitas vezes diversos, uma mesma questão jurídica, até consolidar-se uma única orientação, somente atingível nos Tribunais Superiores - o Supremo Tribunal Federal, o Superior Tribunal de Justiça e, no âmbito trabalhista, o Tribunal Superior do Trabalho. Os juízos de primeiro grau e os tribunais recursais têmse tranformado progressivamente em jurisdições de passagem para o julgamento dos tribunais superiores. ${ }^{54}$

Em verdade, a sentença de primeiro grau tem assumido características de decisão intermediária, algo como que um despacho saneador qualificado, necessário apenas para ensejar a apelação. E o julgamento desta, por sua vez, vem se interlocutorizando como mero requisito de acesso aos recursos extraordinário e especial - com todos os males daí decorrentes, a começar pelo açambarcamento dos tribunais superiores, passando pela imensa produção de recursos intermediários, agravados ante a ansiedade da "provisoriedade satisfativa" e da inserção de teses ad cautelam com vistas ao prequestionamento.

\subsection{A instabilidade jurídica nacional como fator de dispersão jurisdicional}

É comum repetir-se a observação de que a instabilidade nas regras jurídicas nacionais, especialmente na interpretação dos contratos, dificulta a economia do país, atribuindo-se essa instabilidade jurídica à dispersão jurisprudencial. A ob-

52 Previous mediation or Court Annexed Arbitration, esta, em alguns casos, obrigatória, não podendo o caso prosseguir em juízo.

53 Na early neutral evaluation algum juiz da corte examina o caso, com os litigantes, ao início, e diz claramente quem, no seu modo de ver, vai ganhar a açāo, como, quando e quanto e depois tenta conduzir as partes à desistência ou ao acordo, de modo que as partes seguirāo com o processo se o desejarem sabendo, segundo a ótica do julgamento do Estado, o que provavelmente vai acontecer no final.

${ }_{54}$ Fala-se por vezes em necessidade de prestigiar o julgamento de primeiro grau como etapa para a melhoria judiciária, o que sem dúvida é necessário. Mas é parte menor do problema, pois nunca se terá definitividade no julgamento de primeiro grau se não houver firme doutrina de precedentes formada rapidamente nos tribunais superiores e, também, embora em parte menor, nos tribunais de apelaçāo (Tribunais de Justiça e Tribunais Regionais Federais). A dispersão jurisprudencial dos tribunais, permita-se o termo, "tonteia" os juízes de $1^{9}$ grau, as partes e seus advogados. 
servação é em parte correta, quanto à existência de instabilidade jurídica, mas absolutamente falsa, no que tange à responsabilidade do Judiciário por ela. Este, em verdade, é antes vítima da instabilidade jurídica nacional do que produtor dela. E não possui braços capazes de contê-la, pois, enquanto a trilha de um processo dotado de garantias tem de consumir tempo, a alteração das leis no país, inclusive e especialmente a Constituição, anda célere, de tal forma que quando ocorre a criação de verdadeira jurisprudência, isto é, a repetição de precedentes, é comum que as regras jurídicas já tenham se alterado, de maneira que a jurisprudência, em vez de ser prospectiva, passa a ser simplesmente interpretação histórica válida para casos passados.

Aqui vêm os complicadores da estabilidade legislativa no país, entre os quais podem ser destacados: (a) provisoriedade legislativa, ante a demora legiferante definitiva (medidas provisórias, inclusive sobre matérias processuais, rescisória, juros e honorários em desapropriações; alterações em planos de saúde, matéria previdenciária, bancária, direito do consumidor); (b) número de alteraçōes legislativas e constitucionais, ${ }^{55}$ ante a facilidade de efetivação destas últimas, gerando imensa massa de lides sazonais, vindas ao Judiciário como lides individuais e não como "macrolides", que realmente são; ${ }^{56}$ (c) geração legislativa de lides, diante de cada alteração, reabrindo casos já julgados, ante a compensadora recorribilidade (p. ex., reabertura de discussão a respeito de precatórios parcelados; ${ }^{57}$ (d) sistema jurisdicional federativo e caráter nacional do Direito, que tornam naturalmente mais longo o caminho à criação de precedente firme, se este repousa unicamente nas decisões dos tribunais superiores, tomadas individualmente nos numerosos casos que a eles acorrem; (e) ausência de disposiçōes legais e de tradição de estabilidade jurídica.

\subsection{Organização judiciária e dispersão}

A inexistência de tradição de uniformização jurisprudencial acentua-se diante da organização judiciária inadequada. A mesma tese repete-se inúmeras vezes em diferentes turmas, câmaras, grupos e órgãos do mesmo tribunal. É vantajosa a "aposta judiciária", geradora de satisfação provisória, mas concreta, enquanto não julgados recursos pelos tribunais superiores.

P. ex., CF, arts. 93, p. 100-102.

s. 2. Vejam-se as lides decorrentes da correção inflacionária (que atualmente reiniciam no âmbito do Direito Público, mediante a reelaboraçāo de índices por diversas instituiçōes de prestígio, levando à revisão de valores de correção de contratos, vencimentos, proventos e pensões de massa imensa de jurisdicionados que, em conseqüência, ingressam em juízo. Veja-se o produto judiciário das "macrolides sazonais" decorrentes, p. ex., da Lei n" 8.024/90, Lei n" 8.009/90! Sobre o assunto, veja-se, do autor, Assunçāo de competência e fast-track recursal, em Estudos em homenagem a Ada Pellegrini Grinover, DPJ Editora, 2005, p. 790).

5- Sobre a instabilidade nos precatórios ver, do autor, Precatório e mito de Sisifo, in Revista IberoAmericana de Direito Público, v. XVIII, p. 369. 
Nesse ponto situa-se a falência dos mecanismos de produção de jurisprudência estável, como o incidente de uniformização da jurisprudência ${ }^{58}$ e a assunção de competência. ${ }^{59}$ Cria-se, ao contrário do sistema anglo-americano, que próbe o duplo risco, uma espécie de chance do último risco, valendo a pena arriscar o recurso, até que ocorra o julgamento por um juízo favorável, ou até que ocorra algum erro de julgamento que venha a beneficiar o recorrente. ${ }^{60}$

\subsection{Produção de jurisprudência em tribunais complexos}

No sentido de que aqui se cuida, tribunais complexos são os tribunais com grande número de integrantes, em que impossível, como nos tribunais unitários, o julgamento de todos os casos por todos os seus juízes.

Atente-se à diferença entre uma corte unitária, como Suprema Corte dos Estados Unidos, ${ }^{61}$ integrada por nove juizes, que participam, todos, ativamente, de todos os julgamentos, qualquer que seja o ramo do Direito, somente se designando o relator, que escreverá pela maioria, depois de decidido o caso e formadas as correntes de pensamento que o determinaram, ${ }^{62}$ e uma corte complexa, como o

$58 \mathrm{CPC}$, art. 476. Nos tribunais complexos, de que se tratará a seguir, a falência desse instituto é inevitável, pois quem julga a uniformizaçāo é órgāo diverso (Órgāo Especial), com magistrados diferentes, dos órgãos que julgam apelaçōes (Turmas, Câmaras e Grupos), nāo integrantes daquele órgāo e, portanto, menos inclinados, na liberdade jurisdicional de que dispõem, a seguir-lhe o precedente, de cuja formaçāo nāo participaram, e que, por isso, nāo representa propriamente uma "uniformizaçāo", mas, sim, outro julgamento, de cuja formação, repita-se, os integrantes de turmas, câmaras e grupos de tribunais complexos não terão participado e, por isso, não o sendo legalmente, não serão, também, psicologicamente obrigados a seguir.

59 CPC, art. 555, $\$ I^{\circ}$ e 2". Ver, do autor, Assunçāo de competência e fast-track recursal, cit.

60 Em vez de vedação da double jeoppardy, está-se diante de algo como que uma doutrina de multi-jeoppardy - que, contudo, atente-se bem, conforta a parte e seu advogado, que vêem adiado o desfecho desfavorável, ou mantêm a esperança de alguma mudança da lei ou de orientaçāo jurisprudencial, ou, ainda, ao menos, mitigam, econômica ou psicologicamente, o efeito do julgamento indesejado. Esta pretensa teoria do multi-jeoppardy sempre terá numerosos defensores, sob argumentos diversos, como o da recorribilidade irrestrita como garantia de Justiça, da possibilidade de erro de julgamento etc. $O$ grande THEOTÔNIO NEGRÃO, contudo, mirando o Código de Processo de 1973, de que nāo gostava, preferindo o de 1939, costumava dizer, com a verve costumeira, que nosso sistema processual não poderá jamais andar célere, "pois pressupōe que todo juiz erre sempre [...]".

i: US Supreme Court, com 9 Justices, nomeados pelo Presidente da República, vitalícios, inexistente aposentadoria compulsória, presididos por um Chief Justice, também nomeado vitaliciamente, no cargo de Presidente da Corte, pelo Presidente da República, podendo ser nomeado sem antes pertencer à Corte (como o foi o legendário Warren, dos anos sessenta, que era Governador do Estado da Califórnia).

62 Na US Supreme Court, o caso circula, como já se disse, em memorandos, pelos gabinetes de cada juiz, que forma opinião pessoal após o trabalho preparatório de seus assessores (Law Clerks) e leva o caso à discussão semanal (Conference), às quintas-feiras, em sala secreta dos juízes, repetindo-se a discussão tantas vezes quantas seja necessário, até formar-se o pensamento definitivo, de preferência por unanimidade (caso em que geralmente o Presidente da Corte é o relator da decisão (opinion), podendo, contudo, ser designado outro mais habilitado para o caso), estabelecendo-se também, o pensamento da minoria (dissent opinion), que será redigido por algum dos juizes vencidos. Como a redaçāo é minuciosamente analisada por todos, para que todos a subscrevam, os julgamentos realmente são claros e congruentes, fornecendo comando preciso para a sociedade (leading cases), de modo que vinculam a 
Tribunal Superior de Justiça alemão. ${ }^{63}$ Tanto o tribunal unitário como o complexo podem ter competência originária ou derivada, ou mista, respeitando-se, sempre, contudo, nos tribunais complexos, o julgamento especializado segundo a matéria.

Saliente-se: a competência deve ser estabelecida segundo o Direito Material, não segundo o tipo de processo. Foram desastrosas as conseqüências de repartição de lides entre tribunais em São Paulo, segundo o instrumento processual, o que provocava o julgamento da mesma matéria por unidades jurisdicionais diversas, alimentando a divergência e a dispersão jurisprudencial. ${ }^{64}$

Nos tribunais unitários não existe o risco de dispersão jurisprudencial, isto é, de julgamentos divergentes. Nos tribunais complexos, a dispersão somente pode ser evitada pela especialização de órgãos competentes segundo a matéria, ${ }^{65}$ inclusive para a parte processual, ao menos no tocante ao controle da interlocutoriedade. ${ }^{66}$

Seja como for, é irrecusável que apenas um órgão judiciário deva qualificar-se como o juiz natural competente para o julgamento de cada matéria, seja um tribunal unitário, seja uma unidade de tribunal complexo. Pode-se também trabalhar com a instituição de Justiça Especializada, competente para a matéria - como são exemplos a Justiça de Seguros na Suíça e a Justiça Social na Alemanha. O que se tem a todo o custo de evitar é a dispersão jurisprudencial entre órgãos concorrentes para o julgamento da mesma matéria.

\subsection{Complexidade no Tribunal de Justiça de São Paulo}

O caso da Justiça Estadual de São Paulo é sintomático, constituindo atualmente o paroxismo da complexidade, após a fusão dos três tribunais cíveis existentes antes da Emenda da Reforma do Poder Judiciário. ${ }^{67}$

todos os integrantes do meio judiciário (binding precedents), embora nāo tenha havido jamais lei nenhuma que os institua como vinculantes. Note-se que o que vincula é o próprio precedente, não a ementa ou súmula, que, no sistema jurídico, nāo tem valor como citação, signficando apenas orientação para busca em repertórios de jurisprudência, de maneira que nunca a ementa "briga" com o texto, pois só este, inteiro, é que vale como precedente.

63 Bundesgerichtshof (BGH), dividido em câmaras (Senate) especializadas por temas segundo o Direito Material.

${ }^{64}$ Em Sāo Paulo, eram da competência do $1^{\circ}$ Tribunal de Alçada casos que envolvessem títulos executivos extrajudiciais, de maneira que a orientaçāo jurisprudencral sobre a interpretação de um mesmo tipo de contrato podia ocorrer nesse Tribunal, se deduzida em embargos à execuçāo, ou no Tribunal de Justiça ou, mesmo, em alguns casos, no $2^{\circ}$ Tribunal de Alçada Civil, se diretamente movida ação de conhecimento a respeito da matéria!

65 Fala-se em "especialização temática", como insolvência, direito ambiental, consumidor, infância e juventude, enfim, qualquer bloco de competência material.

66 Há experiências de Câmaras para agravos, como no Tribunal de Justiça de Santa Catarina, e como ocorria no extinto $1^{\circ}$ Tribunal de Alçada Civil de São Paulo - abortando-se, infelizmente, essa bem-sucedida experiência, realizada sob a orientaçāo do então Vice-Presidente, ante a unificação dos tribunais de São Paulo, em decorrência da Emenda Constitucional 45/2004.

6. EC 45, de 8.12.2004. 
São 360 Desembargadores no Tribunal de Justiça, divididos, na parte civil, em uma Seção de Direito Privado e outra de Direito Público. A possibilidade de uniformização jurisprudencial é remota, mas a existência, quase sempre, de orientação contrária à do julgamento tomado em um caso concreto incentiva a recorribilidade interna a outros órgãos do tribunal, como os Grupos de Câmaras nas açōes rescisórias, e impulsiona recorribilidade interna, mesmo oblíqua, por intermédio dos embargos de declaração de caráter infringente, repetindo e desenvolvendo argumentos em prol de orientação afastada, na esperança de mudança de orientação individual de integrantes do tribunal, ou de alteração de composição, ou, mesmo, de puro e simples erro de enfoque, sempre possível diante da dificuldade de tratamento de grandes números processuais, em casos muitas vezes semelhantes, mas que se dissociam em pormenores.

Daí a sobrevivência de teses contraditórias no mesmo tribunal, incompreensível, com razão, para os jurisdicionados, que vêem casos absolutamente idênticos receberem desfecho diverso - o que, além de desprestigiar a decisão judicial e, evidentemente, arrefecer o respeito espontâneo da norma, gera o descrédito na Justiça e permite a suposição de influências ignotas, por perseguição ou favorecimento, na produção do julgado desfavorável ou favorável.

Nesse ponto, são incompreensíveis e injustas, aos olhos dos jurisdicionados, embora tecnicamente corretas as declaraçōes, tantas vezes presentes no julgamento das ações rescisórias, no sentido de que a injustiça da decisão não é fundamento para a ação rescisória, ou de que a ocorrência de decisões contraditórias não autoriza a ação rescisória. ${ }^{68}$

Tribunais complexos, com várias turmas, câmaras ou grupos de câmaras igualmente competentes para a mesma matéria são, a exemplo do que ocorre em São Paulo, um dos elementos mais importantes na dispersão jurisprudencial no país e na alimentação dos grandes números da Justiça nacional - com o subproduto em nada desprezível da efetiva degradação qualitativa dos julgados.

\subsection{Insuficiência dos instrumentos de unificação atuais}

Patente a insuficiência dos instrumentos de produção de jurisprudência estável, tanto os instrumentos técnicos de unificação, quanto dos falsos instrumentos de unificação tais como: (a) embargos infringentes (CPC, art. 530); (b) uniformização de jurisprudência (CPC, art. 476); (c) assunção de competência (CPC, art. 555, $\ 1^{\circ}$ ); (d) recurso extraordinário; (e) recurso especial; (f) embargos de divergência; (g) ação rescisória (CPC, art. 485).

\footnotetext{
68 Quantas vezes no julgamento de ação rescisória o integrante do julgamento não tem de rejeitar a ação rescisória contra julgamento que acolheu orientação exatamente contrária a do mesmo julgador em outros casos que tenha julgado! Trata-se de situação extremamente desagradável para o magistrado e, pior, resulta no arrefecimento da própria disposiçāo de fazer Justiça, quando se vê, o julgador, às voltas com julgamento em que, por questão processual, tem de proclamar julgamento diferente do próprio entendimento na questão de fundo.
} 
Se por mais não fosse, o só fato da demora no processamento desses instrumentos já levaria à constatação da insuficiência. Em verdade, produzem eles efeito contrário, pois fazem durar o processo, perdendo-se em andamentos intermediários e incidentais, que só fazem por destruir qualquer possibilidade de formação de linha interpretativa uníssona e estável.

\subsection{Especialização temática nos tribunais}

Nas circunstâncias dos números judiciários nacionais, em que se repetem questões absolutamente idênticas, parece que a solução única possível para a formação, de maneira célere, de jurisprudência estável, situa-se na especialização temática, de acordo com o direito material trazido pela lide, de maneira que um órgão, câmara ou grupo, e apenas um órgão, seja competente dentro do tribunal, para o julgamento da matéria.

Esse órgão pode ser competente para várias matérias, mas não pode, jamais, haver mais de um órgão competente para a mesma matéria. E o número de julgadores desse órgão pode ser maior ou menor, não importa, bastando que todos os julgadores, por serem integrantes do mesmo órgão jurisdicional, decidam juntos, trabalhem em conjunto, o que ensejará a interação entre os magistrados que o componham, de forma que, ao cabo de eventual período de controvérsia, certamente se produzirá o acertamento dos entendimentos, chegando-se à estabilidade de orientação firme, que dará os parâmetros aos Juízes de graus inferiores, aos Advogados no aconselhamento de clientes e, sobretudo, aos agentes da vida jurídica na orientação de seus atos, certos do conhecimento do sentido estável da interpretação do Direito.

Saliente-se que essa especialização nos Tribunais - sobretudo nos Tribunais Superiores, incumbidos da interpretação do Direito Federal de ordem constitucional e infra-constitucional -, é essencial para a firmeza da orientação jurídica no país. E, naturalmente, se ocorrente, praticamente se tornará desnecessário trilhar o longo caminho da produção de súmulas que resumam os julgados, pois os julgados, estes sim, na própria integridade, serão conhecidos, analisados e, naturalmente, seguidos.

A especialização dos Tribunais, relembre-se, foi caminho essencial ao equilíbrio da jurisprudência em outros países. ${ }^{69}$

E deixe-se muito claro que a especialização nos tribunais é muito mais importante do que a especialização de Varas em primeiro grau, conquanto, sem dúvida, também esta seja útil na construção de uma doutrina adequada de precedentes estáveis, que constitui a verdadeira jurisprudência.

69 FRANCISCO DE PAULA XAVIER NETO, Notas sobre a justiça na Alemanha, (Coleção Ajuris, 18). Porto Alegre, 1982. 


\section{9 Órgãos especializados para medidas de urgência}

Medidas de urgência, como as liminares em geral, a antecipação de efeitos da tutela, cautelares, deferimento de efeito suspensivo em agravos de instrumento e cassação de liminares desempenham papel decisivo na dispersão jurisdicional e na instalação de perplexidade entre os usuários da justiça ou agentes de atividades na preparação de seus negócios. Será imprescindível que a matéria liminar seja submetida a um único órgão do tribunal, ao menos para cada tema jurisdicional, tomado o tema do ponto de vista de direito controvertido em juízo, jamais do ponto de vista do instrumento processual. ${ }^{70}$

\subsection{Flexibilização para demandas sazonais repetitivas}

Constituem questōes "sazonais" repetitivas essas que surgem devido à alteração recente da lei, como, entre nós, as decorrentes do bloqueio de ativos financeiros pelo "Plano Collor", de descontos e pagamentos previdenciários, de alterações de regência de planos de saúde, de percentual de juros diante da vigência do novo Código Civil de 2002, de fluência de juros compensatórios no processo expropriatório e tantas outras. ${ }^{71}$

Essas questões exigem o deslinde consistente do embate temático, ou seja da "macrolide", ${ }^{72}$ com urgência, pois, enquanto tal não se obtém, geram imenso número de processos individuais que desagregam a orientação a todo o meio negocial, administrativo e, mesmo, judiciário.

Um caminho é disponibilizar Câmaras para a competência nova, mediante prévia atenção do tribunal para o surgimento futuro da massa de lides "macro", lembrando-se, contudo, que a instituição dessas Câmaras de competência especial sazonal deve preferencialmente dar-se antes do ingresso do caso, para arredar alegações de infringência do princípio do juízo natural. ${ }^{73}$

70 A especialização de órgãos tomando por base o instrumento processual já provocou males imensos ao Judiciário brasileiro. O exemplo mais candente, como já se indicou, talvez tenha sido o da competência dos Tribunais de Alçada de São Paulo, competentes para execuções de título extra-judicial e, naturalmente, de seus embargos, que podiam conter a mesma matéria que, em outros casos, fosse questionada em outro tipo de processo, como o de procedimento ordinário, da competência de outro tribunal - geralmente o Tribunal de Justiça, donde resultava a mesma tese decidida, de maneira contraditória, por dois tribunais diferentes, o que obrigava as partes a forçosamente invocar a atividade dos Tribunais Superiores, para a definiçāo de seus direitos, quando a questāo podia ter terminado no âmbito da Justiça local.

71 No direito estrangeiro há países em que tais questōes se apresentam de forma candente, bastando lembrar as conseqüências da constituição das Comunidades Européias e, depois, da Uniāo Européia, da Glasnost e da Perestroika na Uniāo Soviética e, agora, na Federação Russa, da Reunificação Alemã (Wiedervereinigung) e da abertura do mercado na China!

i2 Sobre "Macrolide", ver, do autor, Assunção de competência e fast-track recursal, cit.

3 Princípio esse, o do Juízo Natural, que, contudo, não impede a formação ulterior das câmaras, porque o juízo natural deve observar-se segundo o princípio do isolamento dos atos processuais, como vem, neste ponto, no art. 132 do Cód. de Proc. Civil, não se imaginando jamais que juízo natural seja 


\section{II Fast-track de relevância}

A organização interna dos tribunais deve prever mecanismos de aceleraçāo de casos de relevância inerente. Essa aceleração é recomendada por diversas consideraçōes de interesse público. Por exemplo, demandas ambientais de larga repercussão regional bloqueiam atividades em áreas e setores de atividades imensos, de maneira que é necessário tratá-las diferentemente de outras demandas individuais, cujos efeitos se restrinjam aos próprios litigantes; demandas de larga repercussão no sistema contratual, como as referentes a contratos bancários, consórcios, planos de saúde e semelhantes, precisam definir-se rapidamente, para orientação dos agentes dessas atividades e dos participantes de seus contratos; e ações movidas por pessoas de idade avançada precisam ter prioridade sobre as demais, para que o término ocorra antes do óbito.

A organização judiciária deve prever mecanismos de fast-track, para andamento diferenciado e célere no sentido da manifestação jurisdicional de cada um dos órgãos judiciários pelos quais tenha de passar o caso até consolidar-se na jurisprudência dos tribunais superiores - e estes, por sua vez, também devem prever mecanismos de tramitação acelerada, para que os casos não se misturem com as numerosas lides individuais em curso.

Entre os exemplos de mecanismos válidos de aceleração na formação de jurisprudência estável situam-se, sem dúvida, a denominada súmula vinculante, prevista pela Emenda Constitucional $45 / 2004,{ }^{74}$ a apelação per saltum e, entre nós, a assunção de competência, determinada pelo art. $555, \mathbb{S} 1^{\circ}$ e $2^{\circ}$, do Código de Processo Civil.

O tratamento diferenciado desses casos permitiria, além disso, o monitoriamento de andamento, evitando que caísse naqueles "pontos mortos" da caminhada processual, tão nocivos à celeridade dos casos judiciais. ${ }^{75}$

um juízo único para toda a duração do processo - interpretação absolutamente estranha a todos os sistemas jurídicos do mundo, pois significaria a eliminação de um dos critérios para a competência, o da competência funcional, clássico, para o nosso sistema, desde a obra de CHIOVENDA.

${ }^{74}$ Quanto às súmulas vinculantes, não se pode antecipar que o resultado positivo será significativo, pois há enormes dificuldades de viabilizaçāo de produçāo de precedentes sumulados entre nós, a começar do princípio da unicidade dos autos processuais, em que se acumulam teses várias, cada qual exigindo uma súmula, de maneira que, contendo os autos algumas matérias sumuladas e outras nāo sumuladas, estas últimas bloqueiem o julgamento final do caso, em que pese a pacificidade de algumas de suas teses. E nāo se olvide que a imaginação de patrocínio jurídico sempre produzirá teses novas, nāo sumuladas, capazes de questionar processos em que o principal seja composto de teses sumuladas há tempos. Isso não ocorre em sistemas estrangeiros, cujo modelo processual não obedece ao princípio da unicidade dos autos, mas, sim, há possibilidade de isolar cada tese em seu próprio arquivo (file) e, assim, rechaçá-la de plano, se já pacificada, ou decidi-la celeremente. Os sistemas são diversos e nāo se confundem as súmulas vinculantes com o stare decisis.

Pesquisa da Min. ELLEN GRACIE NORTHFLEET quando Presidente do TRF em Porto Alegre, demonstrou que o tempo gasto pelos processos em andamento cartorário é bem superior ao consumido pelos juízes para a prolação de suas decisões e sentenças. 


\section{Observações finais}

\section{I Objeções e resistências}

Os mecanismos assinalados, entre outros, todos ligados à organização judiciária, cuja divisibilidade é tradicionalmente esquecida entre nós, podem ser de imensa utilidade na criação de uma jurisprudência estável, à luz da mais avançada doutrina de precedentes.

É claro que se tem de indagar se a sociedade brasileira estará preparada para suportar a estabilidade jurisdicional, ou se prevalecerá a tendência a recusá-la, sob os mais diversos argumentos, alguns dos quais atraentes, como o de que "depende dos integrantes da Câmara", ${ }^{76}$ de que "os juízes foram selecionados politicamente", 77 de que "falta legitimidade a poucos juízes, não escolhidos pelo voto popular", de que "a jurisprudência deve resultar de vários julgamentos discrepantes" - e outros semelhantes, que sempre foram e serão utilizados por quem perca a demanda e pelo Advogado vencido em Juízo, este ante a irrecusável regra psicológica de justificar a derrota perante o cliente, ou, mesmo, de sinceramente confortar-se a si próprio.

Esta é outra faceta do problema. Mas não invalida a conclusão de que, em tribunais complexos, a formação célere de precedentes estáveis somente pode decorrer da especialização temática da competência, de acordo com o direito material trazido pela lide posta em Juízo.

\subsection{Conclusão}

Um Tribunal é um todo orgânico, cujas partes têm de dispor-se no sentido da consecução de um objetivo. No caso do tribunal, tomado como um todo, o objetivo é a produção de uma jurisprudência o mais possível estável, e não apenas de precedentes isolados para casos individualísticos - ou quase egoísticos - das partes litigantes em cada processo.

\footnotetext{
76 Argumento utilizado principalmente para os tribunais de apelaçāo, nos Estados ou na Justiça Federal.

$\because$ Típico argumento apresentado contra os julgamentos do Supremo Tribunal Federal, em que a nomeação de Ministros se realiza, de acordo com o modelo histórico dos Estados Unidos, sob a voluntariedade do Presidente da República, que, evidentemente, indica para o cargo juristas sintonizados com o pensamento político de seu grupo - o que, de resto, é normal no mundo, não significando, sempre, contudo, eterno alinhamento, como a Corte Suprema dos Estados Unidos está cansada de demonstrar (p. ex., os Justices liberais Warren e Brennan, nomeados pelo conservador Einsenhower, que várias vezes disse terem essas nomeaçōes sido seus mais pavorosos erros de governo!), embora muitas vezes seja realmente patente (p. ex., na decisāo sobre a validade da eleição do Presidente George W. Bush para o primeiro mandato, os Justices indicados por Presidentes Republicanos votaram pela validade, enquanto que os nomeados por Presidentes Democratas votaram contra).
} 
Em época de sociedade de massas, não há mais como imaginar a satisfação jurisdicional apenas em cada caso concreto, e de modo contraditório A comunicação social, divulgando, em massa, a contradição, destrói a crença no Poder Judiciário, e incrementa o surgimento de lides, realimentando-se a si próprio.

O Brasil precisa de construção de jurisprudência capaz do respeito da sociedade, não mais apenas de produção de precedentes individuais. A melhor organização dos Tribunais é imprescindível ao aprimoramento da sociedade brasileira. 